\title{
CONATIVE ASPECT OF CIVIL IDENTITY: AN INFLUENCE OF RELIGIOUS AND CONFESSIONAL FACTORS
}

\section{O. Demkiv}

\author{
Ivan Franko National University of Lviv, \\ Universytetska Str. 1, Lviv, Ukraine, 79000, \\ oldemkiv@gmail.com
}

\begin{abstract}
Religious processes play an important role in the life of human civil society. Although there are a lot of works dedicated to the study of the relationship between religion and politics, between religion and the state, far less attention has been paid to the study of the infl uence of religion on the formation of a civil society. The main purpose of this article is to study the infl uence of religion on the development of the conative (pragmatic) aspect of the civil identity of countries in Western and Eastern Europe. The author of the article has used the Index of Civil and Political Activity (ICPA) and the fi gures of declared religious identity according to the 6th round of ESS. As a result, the author has reached the following conclusions: 1) the pragmatic part of civil identity - civil practice - has been growing in most countries in Western and Eastern Europe, while the proportion of citizens identifying themselves with any religion or confession has been declining. 2) There exists a relationship between the religious affi liation and the level of civil and political activity (ICPA is higher in protestant countries)

Keywords: civil society, civil identity, political activity, religion, Index of Civil and Political Activity.
\end{abstract}

Introduction. A characteristic feature of modern democracy is the existence of a stable civil society independent from the state, that can consolidate and deal with certain tasks for the common good. Although civil society exists apart from the state, both work closely within the legal and political framework. The level of development of civil society in each country is defi ned by many factors (such as: the level of social responsibility, development of local self-government and self-regulation, development of mass media, et.) including the level of the existing civil identity ${ }^{1}$.

In recent decades, religion has played a much stronger role in the political sphere, and in many countries (Iran, Israel, USA) has become one of the major social institutions. The impact of different religious movements, and of religious terrorism on world politics can no longer be ignored by researchers. If in Western countries the Christianity church assumes a special role in processes of state building, taking an active position in civil society, in the East

1 Civil identity is a complex phenomenon: realizing by the individual of its identity with a community of citizens of any given state, that is manifested in signifi cant actions aimed to the development of a state.

(C) Demkiv O., 2017 
religions in fact substitutes the civil by creating a special religious-national self-consciousness. Although the process of secularization caused a signifi cant effect on the life of various social institutions, the infl uence of religion on people's behaviour, on the social values of a person and the social groups still remains effi cient.

Nowadays sociological researches concentrate on the disintegration of Eastern European societies, as well as the absence of consolidation and self-organization, the prevalence of individualism, selfi shness and alienation, while the West is demonstrating much higher activity in the societal life. According to the Worldwide Alliance for Citizen Participation, CSOSlis several times higher in the Protestant countries of the Western Europe That is why the study of the infl uence of religion in civil activity is highly topical issue of Sociological Research, as it will answer the question: Why some religions play a more active role in public life than the others? How does the religious affi liation of the nation correlate with its social position today?

Given the above, the purpose of this study is to examine the infl uence of confession and religious affi liation on the conative demonstration of civil identity.

Realization of this purpose is possible with the following objectives: 1) outline the methodology for studying civil identity 2) to determine the probable causes of religious infl uence on the development of civil identity; 3 ) to outline possible models of coexistence of civil society and religion.

1. Review of the Literature. Great attention to studying the role of religion in the social and political transformation of society was paid by the founders of religious sociology Emile Durkheim, Max Weber and Georg Simmel.

Among the most prominent researchers of the secular and the religious remain Ronald Inglehart and Jurgen Habermas. «Sacred and Secular: Religion and Politics Worldwide», a work by Ronald Inglehart and Pippa Norris is one of the most famous in the study of the secular and the religious where, based on the idea of Max Weber and Emile Durkheim, the nature of religion is examined, and societies are classifi ed as sacred or secular [Inglehart, Norris, 2005, p. 5].

Jurgen Habermas considers religious tolerance as one of the components of any liberal political culture. Speaking of «Christian identity of Europe», Habermas stresses civility and democratism [Habermas, 2003].

Of course, it is necessary to give due consideration to Samuel Huntington's civilization model, which predicts the growth of the role of religion in the future, since owing to the

The Civil Society Organization Sustainability Index (CSOSI) has been used since 1997 to assess the sustainability of the CSO sector. The Index has expanded considerably since its inception - it went from covering 18 countries in the Europe and Eurasia Region, to covering over 60 countries in different regions around the world. By using standard indicators and collecting data each year, the CSOSI enables users to track developments and identify trends in the CSO sector over time while allowing for cross-country and cross-region comparison. It is used by CSO advocates, development partners, and academics to assess international and regional trends in the civil society sector and to identify common obstacles impeding the sector's sustainability, such as the legal environment, organizational capacity, and fi nancial viability

22013 CSO Sustainability index for central and eastern Europe and Eurasia. Available at http:// www.usaid.gov/sites/default/fi les/documents/1863/2012CSOSI_0.pdf 
response to global social and economic problems, the main differences between people will not be associated with economy, politics or ideology, but with culture [Huntington, 1993].

Notable are also the ideas of David Hollenbah, the Centre for Human Rights and International Justice Director (USA, Boston). In his works [Hollenbach, 2003,2006,2007] he claims that religious ideas may promote democracy, human rights and the world, taking an active position in civil society. The researcher raises the question of the correlation between liberalism and religious freedom, the importance of religion in a pluralistic society, the privatization of religion in domestic policy and the benefi ts of religion for civil society. He analyzes the Christian ethic during the Cold War, the role of Catholicism in Communist countries, the observance of human rights in Africa and global universal ethics.

The infl uence of religious identity on the formation of civil society was also studied by M. Marynovych and A. Turii, whose works deal with the importance of the church in postcommunist countries and fi nding religious identity [Marynovych, 2004]. Works by R. Protsiuk [Protsiuk, 2004] are devoted to the religious aspect of nation-building, and its relationship with the processes leading to the formatiom of a civil society. The value of religion in the life of human society was studied by Benedict Anderson, Dominique Schnapper, I. Ohiienko, A. Kolodii, and A. Karas. In the observable thesis of the Russian sociologist M.V. Yefriemova, the synergies between civil and religious identities and economic units and concepts are examined [Yefriemova, 2010].

In general, the analysis of the literature on the research has allowed us to distinguish two main areas: 1) the theoretical analysis of the content of the concepts of «religious» and «civil» identity, as well as civil society; 2) and social interdependence of civil and religious life in society.

2. Research Methodology. During the investigation of social identities, the theoretical approach of J. Turner and H. Tajfel about the effects of interpersonal and inter-group communication on identity formation (Social Identity Theory) [Tajfel, 1982] is usually used; it defi nes the latter as the part of individual identity that arises from an awareness of their membership in a social group with axiological and emotional signifi cance. That is, the individual identifi cation as a member of a particular group, and the emotional signifi cance of the members of this group.

In determining the degree of identifi cation with the group, Petr Shtompka [Sztompka, 2005] distinguishes subjective attitude and objective membership.

As we combine these two approaches, we may distinguish between the indicators of social identity (including civil and religious and confession) between a subjective attitude that comes laden with gnostic (cognitive) and axiological and emotional stress, and the as objective membership that is defi ned by membership activity, or by any other practices (see Fig. 1)

Thus, the empirical indicators of civil identity formation are its cognitive, axiological and emotional content, and the implementation of a citizen's advocacy in specifi c activities are realized through civil practices. At the center of our research is the conative (behavioral, pragmatist) aspect because it has the greatest importance on the formation of an integrated civil identity and manifests itself in specifi c actions important for society, practices.

In sociological studies of behavioral forms of interaction between citizens and the state, a concept of political contribution is usually used, because most forms of political contribution 


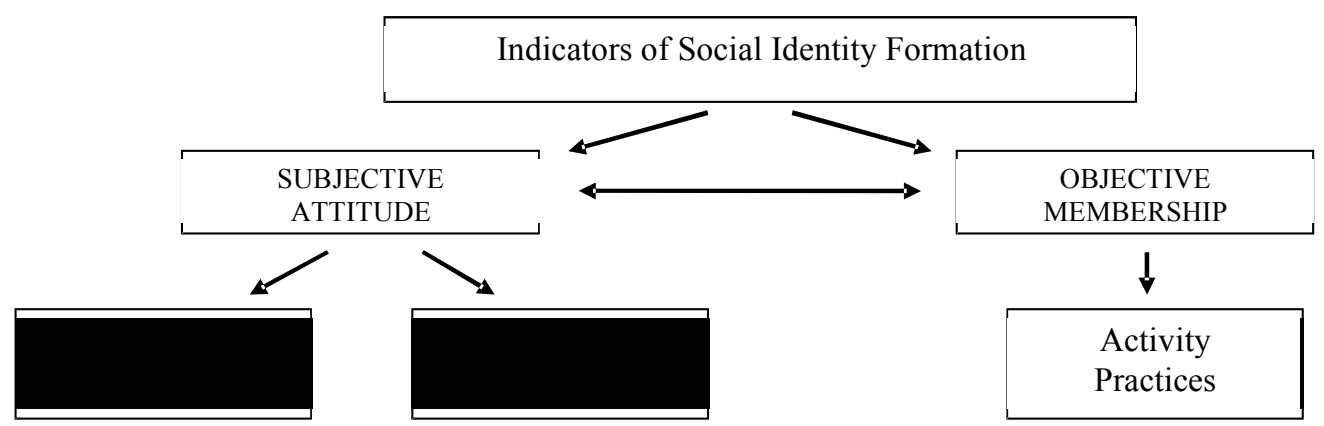

Figure 1. Key Indicators of Social Identity Formation

are particular manifestations of defending one's own interests and preferences. However, some forms of political contribution, such as voting in elections or referendums, do not always have the nature of innovative actions by the citizens.

Electoral behavior, in one respect, may be considered as an act of will, but it is problematic to attribute this act to innovation, since the election and possibility to vote defi ned by institutional factors (even in countries with no civil society) and these factors do not actually depend on the individual will. The concept of political contribution focuses precisely on the political form of action. Value system as an important source of contribution is often carried forward to political contribution. Also, political contribution, in addition to behavioral forms, involves cognitive inclusion. In particular, the levels of political interest or apathy, of party membership, understanding of political issues, etc. [Reznik, 2009] are considered as a criterion for political contribution.

Although a lot of work has been devoted to theoretical approaches that explain the mechanisms and factors of civil engagement, the most noteworthy are the developments of British researchers Charles Pattie, Patrick Seyd, Paul Whiteley [Pattie, Seyd, Whiteley, 2003], Robert A. Dahl [Dahl, 1961], and the Ukrainian sociologist O. Reznik [Reznik, 2009, p. 16]. Based on this research, we build an operational approach to the conative aspect of civil identity, civil and political practices, which includes the following:

- Conventional practices such as regular party work, active participation in the party, the use of political insignia, contacts with government offi cials; contacts with activists, political organizations; work at election headquarters; work in civil society organizations, and other work that involves informing people along a political line;

- Non-conventional practices such as non-violent institutionalized behavior (legitimate demonstrations, public rallies, marches, pickets, boycotts, and occupation of premises); non-violent illegitimate actions (civil disobedience, participation in illegal strikes, demonstrations); violence (terrorism, rebellion, road blocking, acquisition by seizure, clashes with the police, causing damage to property);

- Various activities resulting from citizens contacting institutions and organizations (writing complaints, petitions, appeals to local governments and public administrations); 
- Citizens' organizational (group) practices (participation in the activities of civil organizations).

As a generalized indicator of civil practices we have used an Index of Civil and Political Activity (ICPA) proposed by O.A. Borovskyy [Borovskyy, 2011, p.119]; this Index is calculated based on the results of the European Social Survey (ESS) as a group mean of the average values (for each country) of variables ESS B13 (Have you got in touch with any politician, government or local authorities during the last 12 months?), B14 (Have you worked in any political party or movement?), B15 (Have you worked in another organization or association?), B16 (Have you worn any political symbols (icons, ribbons, pennants etc.) or distributed campaign materials?), B17 (Have you signed any petition?), B18 (Have you participated in a lawful public demonstration?), and B19 (Have you participated in the boycott of any industrial products or food during the last 12 months?).

During our survey, we also use the indicator of declared religious and confessional identity, as in this case, it is the area of religious confession of a respondent that we are interested in, and not the depth and fullness of his religion. In the European Social Survey (ESS) it is measured by an indicator of the respondent's self-identifi cation with a particular religion and confession (the question «Do you belong to any particular religion or confession?»).

3. Empirical Study of the Relationship of Religiosity and Civil Identity. The interdependence of civil and religious identities nowadays has been confi rmed by comparative studies by ESS, Euro Barometer, European Value Survey, SINUS-Milieu, INTAS and others. In particular sociological monitoring project ESS (European Social Survey) provides a real opportunity for the researcher to compare with multiple indicators of social and political life of Western and Eastern Europe.

As it can be seen, the pragmatic part of civil identity, civil practice, increases in most countries of Western and Eastern Europe along with the decrease of the population that identifi es itself with any religion or affi liation (see fi g. 2). Countries such as Sweden, Norway, Finland, Germany, Denmark, and France which all had their identifi cation with a particular religion or belief confi rmed by almost $60 \%$ of respondents, are the most active in civil activity and politics. On the contrary, countries with high religious activity, Cyprus (0.97), Romania (0.93), Poland (0.89), and Portugal (0.86), have the lowest rate of participation in civil practice: $0.09 ; 0.04 ; 0.06$ and 0.04 respectively.

As for religious and confessional identifi cation, in this context a direct connection with civil activity may be seen (picture 3). Based on these data, we may distinguish three groups of countries with a similar set of values of parameters:

1) countries with a high ICPA $(\geq 0,12)$ and an average indicator of declared religious identity (less than 70\%): Sweden, Norway, Finland, Germany, Spain, Switzerland, France, Denmark, Great Britain, Belgium, the Netherlands;

2) countries with a low ICPA $(\leq 0,11)$ and a high rate of declared religious identity (70\%): Cyprus, Slovakia, Ukraine, Bulgaria, Poland, Romania, Portugal;

$3)$ countries with a low ICPA $(\leq 0,11)$ and a low rate of declared religious identity (less than 60\%): Estonia, Hungary, Latvia, Russia, Slovenia.

It is characteristic that countries with a protestant orientation are prevalent in the fi rst public group, and Catholics and Orthodox dominate in the second and third groups. Moreover, 


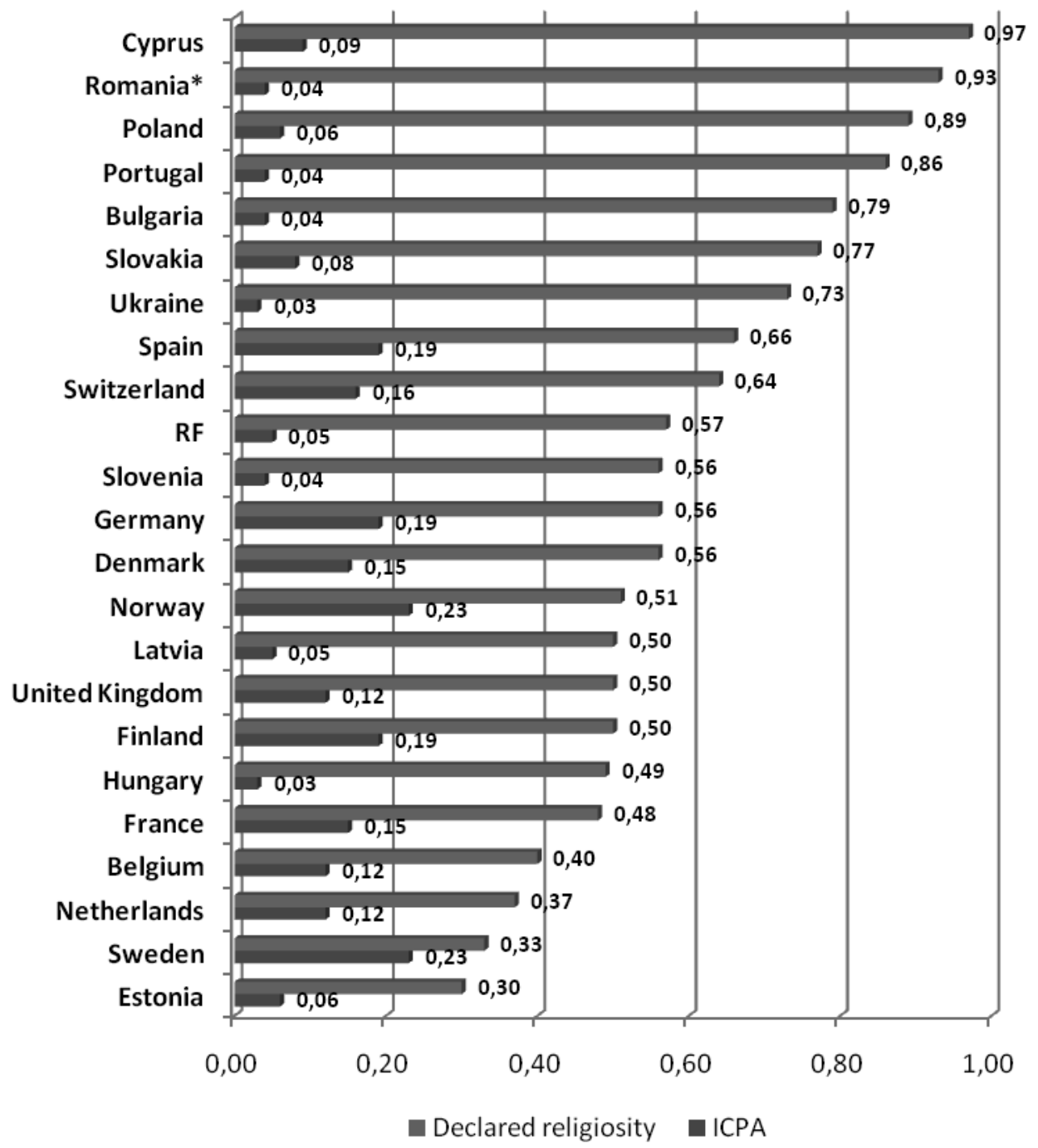

Figure 2. Declared level of religiosity and valued ICPA (ESS, Round 6-2012)

(The source: European Social Survey)

an interesting tendency is seen: the higher is the percentage that identifi es itself with Orthodoxy in the country, the lower is the ICPA, which confi rms Samuel Huntington's opinion: «Europe ends where Western Christianity ends and Islam and Orthodoxy begin» [Huntington, 1993, p. 243].

This dependence is explained by difference in the ideological doctrines of Orthodoxy, Catholicism and Protestantism. While monarchy is an ideal form of government for Orthodoxy and Catholicism, which is declared in religious discourse («For the LORD is our judge, the LORD is our lawgiver, the LORD is our king; it is he who will save us» (Isaiah 33:22)) - , 


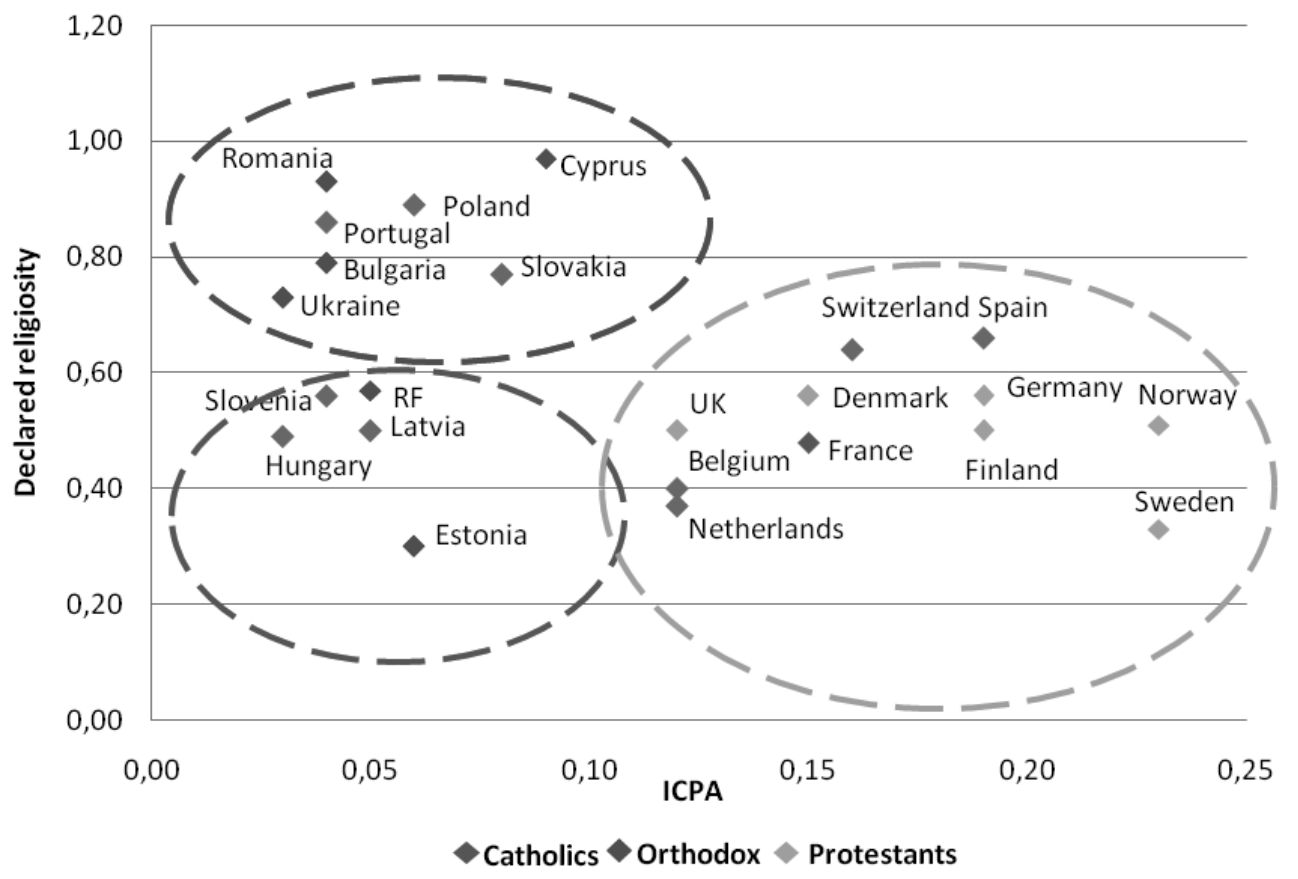

Figure 3. The relation of religion and ICPA, (ESS, Round 6-2012) The source: European Social Survey)

Protestantism is a supporter of democratic principles, a model of commonwealth that would guarantee human rights and freedoms, independent legislative and judicial system: «First, we must provide a sound basis for the civil law and sword so no one will doubt that it is in the world by God's will and ordinance» [Wells, 2010, p. 81]. This hypothesis is supported by empirical data of ESS Round 6.

As it may be seen on the fi gure 4, the number of people who support democracy is increasing along with the increase of Protestants. The lowest rate of adherence to democratic values is in Russia (6.55), where Orthodox religious model of world perception was long under the infl uence of different emperors. The questions of internal and external freedom in this religious doctrine, are a point of dispute in various religious doctrines: the Western traditions developed the idea of the values of freedom from political space, while subordination to groups, individuals or entities dominated in the East. The belief in a wise ruler, the Holy Father, and unsophisticated law, all this leads to a unique model of civil behavior. Orthodox theology of suffering and salvation goes back to the times when Kievan Rus adopted Christianity. The model of so-called «Moscow Orthodoxy», which is now present in the countries of Eastern Europe, was formed, according to Anthony D. Smith, during the fall of Constantinople, which promoted closer union of church and state, as well as the development of the idea that Russia is the last bastion of the true faith. At that time when the Russian Church got the status of «national autocephalous», and the religious community became equal to the political, the 


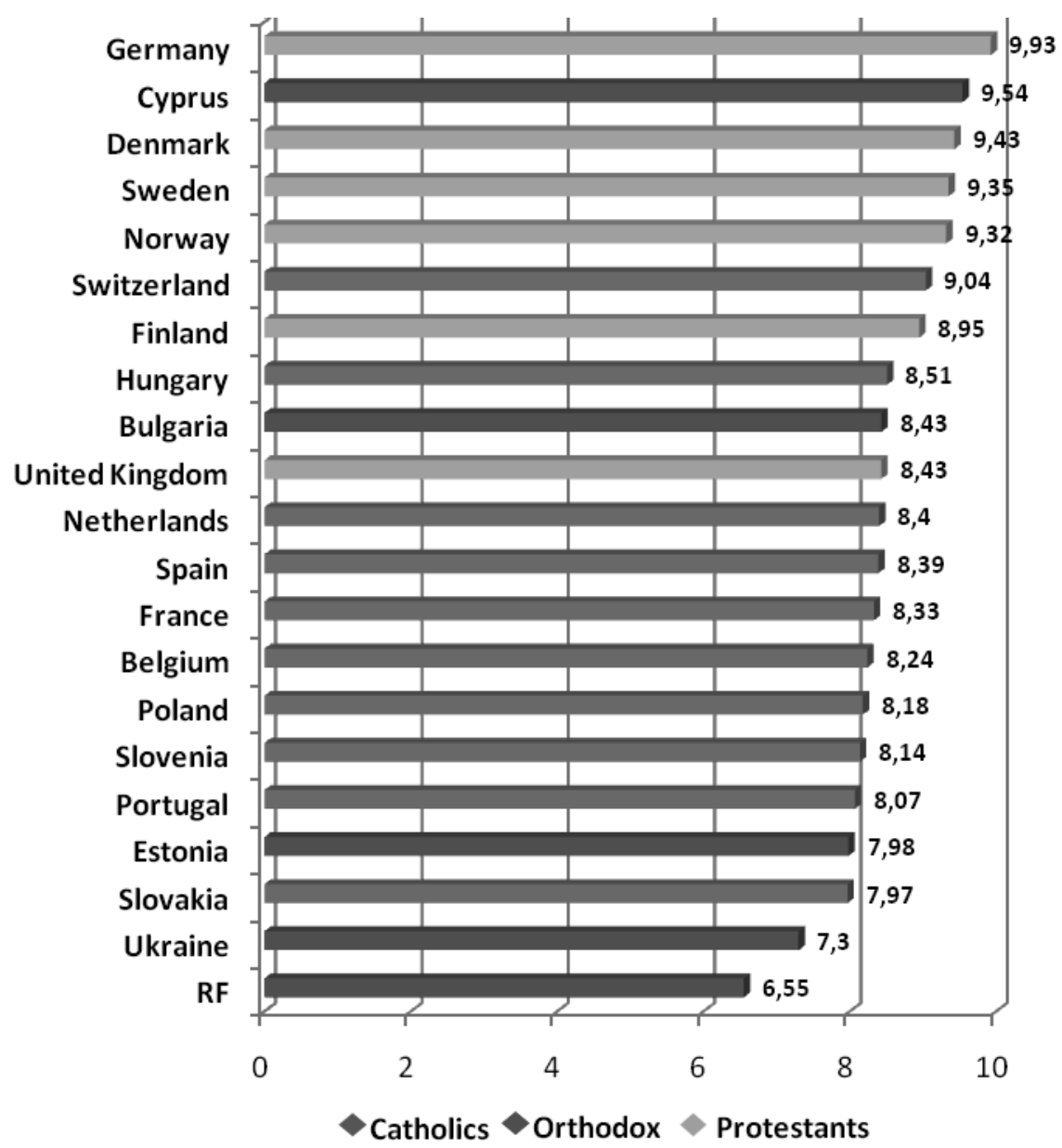

Figure 4. The importance of the democratic for of govervenment repondents in European countries ICPA Round (ESS, Round 6-2012)

The source: European Social Survey)

state itself became more autocratic, and its rulers deliberately adopted Byzantine titles such as autocrat («sole ruler») and «Tsar», as well as the Byzantine palatial ceremonial and emblems, such as the Byzantine double-headed eagle [Smith, 2008].

Another inherent part of civil society is the support of democratic values. According to A. Ivin [Ivin, 2000], real democracy is possible only if there is a stable civil society able to use democracy as a tool for reconstruction (rebuilding) of a country. On the other hand, the existence of the civil society governed by rules and established by the state, turns out to be more stable and productive if democracy is a crucial means of infl uencing the state. Such relation between democracy and civil society is the key to understanding democracy and explaining why in countries where the government was not reined in by a sustainable civil society, democracy becomes ineffective and sometimes even harmful [Ivin, 2000, p. 161]. 


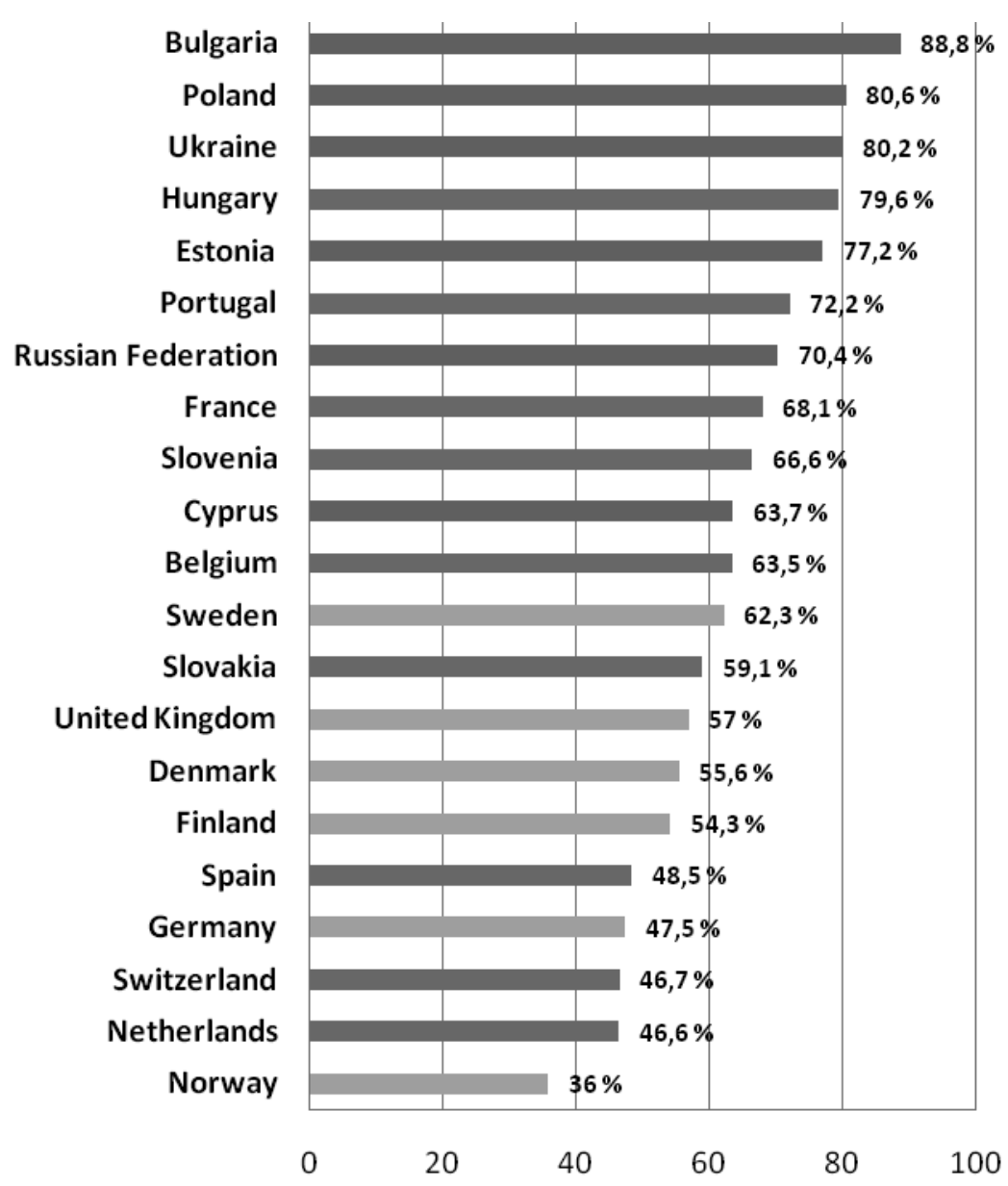

Figure 5. Involved in work for voluntary or charitable organisations: proportion respondents who never took (ESS, Round 6-2012)

The source: European Social Survey)

Unlike the constant struggle and confrontation by Orthodox and Catholic churches for the right to put their mark on society, the Protestant doctrine provides for cooperation in the fi eld of «state-society-personality».

Another important indicator of civil engagement is voluntary participation in various social movements and organizations (volunteering). Participation in voluntary activities is a reliable indicator of civil identity, because it refl ects the degree of civil engagement (fi gure 5). As it may be seen, the percentage of people who have never participated in volunteer work is higher in countries with Orthodox and Catholic religion (Bulgaria, Poland, Ukraine, Hungary, Estonia and others).

Conclusions. Thus, upon our research we can draw the following conclusions:

- the ideological foundations of civil society were formed in those countries where 
Protestantism became one of the dominant faiths. The countries with a protestant orientation are prevalent in the groups with a high ICPA, and Catholics and Orthodox dominate in the groups with a low ICPA;

- $\quad$ in general, for the developed Western democracies the religious component is not one of the dominant ones in the formation of civil identity, where religious identity is often identifi ed with national identity - which is connected with the long struggle between Catholicism and Protestantism, which had as a consequence the appearance of various national liberation movements;

- some countries of the Western Europe have moved towards a certain privatization of religious identity. While nowadays democratization processes in the world churches increasingly emphasize on its separation from the state, its role in the political and diplomatic activity, especially in transitional societies, is continually increasing;

- the main reasons for the- different infl uence of religion on civil activity of the population are: fi rstly, historical factors - traditionally, the strongest indicator of religiosity is observed in countries where the Church was a strong social institution; secondly, the difference between ideological doctrines and principles of outlook in world religions;

- the main differences between religious infl uence are in the ideological and philosophical bases of religions and in their interpretation of existence and the way of life.

- the confrontation between religious and civil identity is evident in the Orthodox countries that is the bearer of a particular worldview which was formed throughout thousand years of history and tradition. Having inherited the Byzantine tradition, «Orthodoxy» became a dedicated follower of power «established by God», in other words, monarchical power that derives from the inability of its supporters to organize and consolidate. For a long time, «imperial» Orthodoxy of Eastern Europe held in its hands state, church and nation, which proved itself in such phenomena as paternalism, low public activity, civil derivation, et-cetera.

\section{REFERENCES}

1. Inglehart, R., Norris P. (2005), Sacred and Secular: Religion and Politics Worldwide, Psychology Press, $405 \mathrm{p}$.

2. Habermas, J. (2003) Faith and Knowledge, In The future of Human Nature, p. 101-115.

3. Huntington, S. (1993), The Clash of Civilization?, Foreign Affairs.

4. Hollenbach, D. (2003), The Global Face of Public Faithby, Washington, DC: Georgetown University Press, $259 \mathrm{p}$.

5. Hollenbach, D. (2006), Human Rights, Justice and the World Church, The national catholic weekly «America», Vol. 195, no. 13, p. 10-12.

6. Hollenbach, D. (2012), Religious Freedom, Morality, and Law: John Courtney Murray Today, Journal of Moral Theology (Inaugural Issue), no. 1, 69-91.

7. Marynovych, M. (2004), An ecumenist analyzes the history and prospects of religion in Ukraine, Lviv: Ukrainian Catholic University Press, 89 p.

8. Protsiuk, R. (2004), Nation's Religious Identity as a Factor of Civil Society, Bulletin of the Lviv University. Philosophy, Vol. 6, p. 122-130. 
9. Yefriemova, M. (2010), The relation of civil and religious identity with economic attitudes and perceptions, Moscow, $29 \mathrm{p}$.

10. Tajfel, H. (1982), Social identity and intergroup relations. Psychology., Cambridge, Paris.

11. Sztompka, P. (2005), Analysis of contemporary society, Moscow, 664 p.

12. Reznik, O. (2009), Explanatory opportunities of the theoretical appoaches to the study of civil practice factors, Ukrainian society, Vol. 4, no. 31, p. 150-159.

13. Pattie, Ch., Seyd, P., Whiteley, P. (2003), Citizenship and Civic Enga-gement: Attitudes and Behaviour in Britain, Political studies, Vol. 51, p. 443-468.

14. Dahl, R.A. (1961) Who governs? Democracy and power in an American city, New Haven; Lnd., 357 p.

15. Reznik, O. (2009), Civil Practices in the Transition Society: Factors, Subjects, Methods of Realization, Kyiv: Institute of Sociology, NAS of Ukraine, $336 \mathrm{p}$.

16. Borovskyy, O.A. (2011), Methodical and methodological foundations for the course «Transformation processes in Central and Eastern Europe», Kyiv, Actual problems of sociology, psychology, pedagogy, no. 13, p. 115-121.

17. Wells, S. (2010), Chrastian ethnics: an Introductory reading, Wiley-Blackwell, 335 p.

18. Smith, A. (2008), The cultural Foundations of Nation: Hierarchy, Covenant, and Republic, Wiley-Blackwell, $264 \mathrm{p}$.

19. Ivin, A. (2000), Philosophy of History, Moscow, 528 p.

Стаття надійшла до редколегії 12.06.2017

Прийнята до друку 17.08.2017

\title{
КОНАТИВНІ АСПЕКТИ ГРОМАДЯНСЬКОЇ ІДЕНТИЧНОСТІ: ВПЛИВ РЕЛІГІЙНОГО ТА КОНФЕСІЙНОГО ЧИННИКІВ
}

\author{
О. Б. Демків \\ Львівський національний університет імені Івана Франка, \\ вул. Університетська 1, Lviv, 79000, Україна, \\ oldemkiv@gmail.com
}

\begin{abstract}
Релігійні процеси відіграють важливу роль у житті громадянського суспільства. Хоча існує корпус праць, присвячених вивченню взаємозвязків між релігією та політикою, між релігією та державою, набагато менше уваги приділялося вивченню впливу релігії на формування громадянського суспільства. Головна мета цієї статті зясування взаємозвязку релігії та конативного аспекту громадянської ідентичності країн Західної та Східної Європи. Автор статті використовував Індекс громадянської та політичної діяльності (ICPA) та показники декларованої релігійної ідентичності відповідно до шостої хвилі Європейського соціального дослідження. У розвідці 3'ясовано: 1) прагматична частина громадянської ідентичності - цивільна практика зростає в більшості країн Західної та Східної Європи, тоді як частка громадян, які ідентифікують себе з будь-якою релігією чи конфесією спадає 2) існує зв'язок між релігійною приналежністю та рівнем громадянської та політичної активності.

Ключові слова: громадянське суспільство, громадянська ідентичність, політична діяльність, релігія, індекс громадянської та політичної діяльності.
\end{abstract}

